\title{
Pengaruh Asam Traneksamat Praoperasi Terhadap Pendarahan Perioperatif Tumor Otak Glioma yang Sedang Mendapat Deksametason
}

\author{
Julius July
}

\begin{abstract}
Abstrak
Pendahuluan : Penggunaan deksametason kontinyu pada penderita tumor otak mengganggu koagulasi darah, disamping itu terjadi peningkatan aktifitas fibrinolisis selama operasi pengangkatan tumor. Penelitian ini dilakukan untuk menilai pengaruh asam traneksamat praoperasi terhadap jumlah pendarahan perioperatif penderita tumor otak yang sedang mendapat pengobatan deksametason.

Metode : Penelitian dilakukan mulai tanggal 1 Mei 2005 sampai dengan 30 September 2005, terhadap penderita glioma dewasa ( $\geq 18$ tahun) yang sedang mendapat pengobatan deksametason selama minimal 1 minggu, kemudian menjalani operasi pengangkatan tumor. Penelitian ini merupakan uji klinik dengan randomisasi sederhana antara kelompok perlakuan yang mendapat asam traneksamat $20 \mathrm{mg} / \mathrm{kgBB}$ dosis tunggal praoperasi dan kelompok kontrol. Estimasi jumlah pendarahan perioperatif (intraoperatif dan pascaoperasi) dan kadar D-Dimer diukur pada kedua kelompok. Analisis statistik menggunakan uji T, uji Mann-Whitney, uji eksak Fisher, analisis korelasi rank Spearman dan regresi dengan kemaknaan berdasarkan nilai $p<0,05$.

Hasil : Jumlah subjek adalah 17, terdiri dari 11 laki-laki dan 6 perempuan; 9 penderita menerima perlakuan. Jumlah pendarahan rata-rata pada kelompok perlakuan adalah $367,0+156,8 \mathrm{cc}$, lebih sedikit jika dibandingkan dengan kelompok kontrol $528,1 \pm 118,9 \mathrm{cc}\left(\mathrm{Z}_{\mathrm{M}-\mathrm{w}}=2,04 ; p=0,043\right)$. Aktifitas fibrinolisis (D-Dimer) lebih rendah pada kelompok perlakuan $\left(\mathrm{p}_{\mathrm{EF}}<0,001\right)$. Pengaruh asam traneksamat semakin menurun dengan masa operasi yang semakin lama $(p=0,039)$ dan jumlah pendarahan mengikuti persamaan regresi $\mathrm{P}=0,454+(1,692 \times$ lama operasi).

Diskusi : Pemberian asam traneksamat praoperasi dapat mengurangi jumlah pendarahan perioperatif pada penderita tumor otak yang sedang mendapat pengobatan deksametason.
\end{abstract}

Kata kunci : asam treaneksamat, deksamethason, D-Dimer, glioma, pendarahan perioperatif. (J I Bedah Indones. 2007; 35(2): 42-7)

\section{The Effect of Preoperative Tranexamic Acid on Perioperatif Hemorrhage in Glioma Patients Receiving Dexamethasone}

\begin{abstract}
Introduction: The majority of brain tumor patients tend to require dexamethasone despite their potential adverse effect on blood coagulation. Moreover excessive fibrinolysis could be induced during tumor removal, possibly adding to the coagulopathy. The aim of this study was to determine the effect of preoperative tranexamic acid on perioperative hemorrhage in brain tumor patients receiving dexamethasone.

Methods: This is a prospective study of adult glioma patients ( $\geq 18$ years old) receiving dexamethason for at least 1 week prior to tumor removal, conducted from 1 May 2005 to 30 September 2005. Patients were randomized to either the treatment group, receiving tranexamic acid, or the control group who did not. The treatment group received $20 \mathrm{mg} / \mathrm{kgBW}$ tranexamic acid on induction of anesthesia, 30-60 minutes before skin incision, as a single dose. Estimated perioperative (intraoperative and postoperative) blood loss and D-Dimer levels were measured in both groups. Statistical analysis was done using T-test, Mann-Whitney test, and Exact Fisher test, whereas correlation analysis were performed using rank Spearman and regression with significance level based on $p<0.05$.

Results: There were 17 patients included in this study, consisting of 11 males and 6 females, nine of them were randomized to the treatment group. Mean hemorrhage for treatment group was $367.0 \pm 156.8 \mathrm{cc}$, which was less when compared to the control group $528 \pm 118.9 \mathrm{cc}\left(Z_{\mathrm{M}-W}=2.04\right.$; $p=0.043)$. Fibrinolysis (D-Dimer) was also lower for the treatment group $\left(p_{E F}<0.001\right)$. The effect of tranexamic acid declined following the length of sugery $(p=0.039)$ and the blood loss followed the regression formula $P=0.454+(1.692 x$ length of surgery).

Discussion : Preoperative tranexamic acid could reduce perioperative hemorrhage in brain tumor (glioma) patients who were receiving dexamethasone.
\end{abstract}

Keywords : dexamethasone, D-Dimer, glioma, perioperative hemorrhage, tranexamic acid. (J I Bedah Indones. 2007; 35(2): 42-7)

\section{PENDAHULUAN}

Rembesan pendarahan yang sulit dihentikan (oozing) sering ditemukan pada saat operasi tumor otak, terutama jika penderita sedang mendapat pengobatan deksametason dosis tinggi. Rembesan pendarahan tersebut dapat meningkatkan jumlah pendarahan selama operasi dan menambah kebutuhan transfusi darah. Peningkatan jumlah pendarahan akan mempengaruhi morbiditas dan mortalitas pascaoperasi.

Upaya mengurangi pendarahan perioperatif, dapat dilakukan dengan pemberian antifibrinolisis seperti aprotinin, asam traneksamat, asam $\varepsilon$-amino kaproat, dan lain-lain. ${ }^{1}$ Kelebihan asam traneksamat dibandingkan yang lain adalah berharga lebih murah, lebih aman, pemberiannya lebih mudah, sehingga dapat diberikan tanpa menambah beban biaya yang 
berarti. Penelitian ini bertujuan menelusuri apakah asam traneksamat yang diberikan dalam dosis tunggal sebelum operasi dapat mengurangi jumlah pendarahan perioperatif (intraoperatif dan pascaoperatif) pada penderita tumor otak yang sedang mendapat pengobatan deksamethason.

\section{METODE}

Subjek penelitian yang digunakan adalah penderita tumor otak yang sedang mendapat pengobatan deksametason selama minimal 1 minggu $^{2}$ menjelang operasi elektif kraniotomi pengangkatan tumor dan memenuhi kriteria inklusi. Kriteria inklusi meliputi : usia subjek 18 tahun atau lebih, diagnosis tumor otak ditegakkan berdasarkan gambaran CT Scan atau MRI, menunjukkan ciri-ciri tumor intrinsik (glioma), dan lokasi tumor di supratentori.

Penderita dieksklusi dari penelitian jika 1) pada temuan intraoperatif ternyata bukan glioma, dan dikonfirmasi dengan hasil pemeriksaan patologi anatomi, 2) hanya dilakukan biopsi terhadap tumor, 3) memiliki riwayat penyakit yang dapat menimbulkan gangguan koagulasi atau hasil pemeriksaan laboratorium praoperasi memperlihatkan gangguan koagulasi, 4) menggunakan heparin atau obat antikoagulan sejenis, 5) memiliki gangguan ginjal, 6) sedang hamil.

Jenis penelitian ini adalah uji klinik pada penderita tumor otak yang sedang mendapat pengobatan deksametason sebelum operasi, kemudian dilakukan pengukuran estimasi jumlah pendarahan perioperatif pada kelompok penderita yang mendapat perlakukan dan kelompok kontrol. Semua operasi dilakukan oleh satu operator dibantu oleh residen tingkat akhir. Penilaian aktifitas fibrinolisis segera dilakukan setelah operasi selesai melalui pemeriksaan D-Dimer dan hanya dilakukan pada penderita yang tidak mendapatkan transfusi darah selama operasi. Penentuan kelompok perlakuan atau kontrol dilakukan dengan randomisasi sederhana memakai tabel angka random terhadap urutan operasi penderita.

Variabel yang diteliti adalah estimasi jumlah pendarahan perioperatif, dengan variabel penunjang antara lain 1) kadar hemoglobin sebelum dan sesudah operasi, 2) kadar hematokrit sebelum dan sesudah operasi, 3) kadar trombosit sebelum dan sesudah operasi, 4) kadar D-dimer sesudah operasi, 5) profil koagulasi sebelum dan sesudah operasi, 6) lama operasi berlangsung, 7) volume tumor yang dihitung berdasarkan formula: È/6 (panjang x lebar x tinggi) dari gambaran CT Scan atau $\mathrm{MRI}^{3}$, 8) jumlah transfusi yang diberikan, 9) hasil akhir penderita sebelum pulang. Selain itu dicatat pula karakteristik penderita, yang meliputi jenis kelamin, umur, tinggi badan, berat badan, dan indeks massa tubuh (BMI = body mass index).

Estimasi jumlah pendarahan intraoperatif yang diukur merupakan hasil penjumlahan dari 1) jumlah darah yang terdapat dalam botol penghisap dan wadah penampung di bawah meja operasi dikurangi dengan jumlah cairan irigasi $(\mathrm{NaCl} 0,9 \%)$ yang terpakai, 2) selisih berat kasa sebelum dan sesudah digunakan untuk mengusap darah, dengan perhitungan bahwa $1 \mathrm{cc}$ darah ekivalen dengan 1 gram, ${ }^{4} 3$ ) rata-rata jumlah darah yang melekat pada kain operasi yaitu lebih kurang $40 \mathrm{cc}$. $^{5}$

Estimasi jumlah pendarahan pascaoperasi dinilai dari jumlah darah dalam drain sesaat sebelum drain dibuka pada 24 jam pertama setelah operasi.

Penimbangan dilakukan dengan timbangan ACS-LCD great scale berkapasitas 3000 gram dengan ketelitian 0,1 gram. Setiap kasa yang telah diusap dengan darah, sebelum dibuang ke wadah, dikumpulkan terlebih dahulu dan ditimbang. Penimbangan terhadap kasa yang telah diusap darah tersebut dilakukan secara berkala karena kasa yang dibiarkan terlalu lama akan mengering sehingga beratnya berkurang.

Analisis data untuk membandingkan perbedaan dua ratarata digunakan uji T, dan uji Mann-Whitney untuk data yang tidak berdistribusi normal, sedangkan untuk membandingkan data kualitatif (data yang tidak disusun dalam tabel kontingensi) digunakan uji eksak Fisher. Analisis korelasi rank Spearman dan regresi digunakan untuk mengetahui hubungan antara jumlah pendarahan dengan lama operasi dan persen volume tumor yang terangkat. Kemaknaan ditentukan berdasarkan nilai $p<0,05$.

\section{HASIL}

Karakteristik penderita yang masuk dalam penelitian ini dapat dilihat pada Tabel 1. dan distribusi pada kedua kelompok cukup homogen.

Tabel 1. Karakteristik penderita tumor otak pada kelompok perlakuan dan kontrol

\begin{tabular}{|c|c|c|c|}
\hline \multirow[b]{2}{*}{ Karakteristik } & \multicolumn{2}{|c|}{ Perlakuan } & \multirow[b]{2}{*}{ Kemaknaan } \\
\hline & $\begin{array}{c}\text { Asam traneksamat } \\
(\mathrm{n}=9)\end{array}$ & $\begin{array}{l}\text { Kontrol } \\
(\mathrm{n}=8)\end{array}$ & \\
\hline \multicolumn{4}{|l|}{ 1. Jenis kelamin } \\
\hline - Laki-laki & 4 & 7 & \multirow[t]{2}{*}{$p_{\mathrm{EF}}=0,131$} \\
\hline - Perempuan & 5 & 1 & \\
\hline \multicolumn{4}{|l|}{ 2. Umur (tahun) } \\
\hline $\mathrm{X}(\mathrm{SB})$ & $32,6(12,5)$ & $45,6(10,5)$ & \multirow{3}{*}{$\begin{array}{c}\mathrm{Z}_{\mathrm{M}-\mathrm{W}}=1,884 \\
p=0,060\end{array}$} \\
\hline Median & 35 & 44 & \\
\hline Rentang & $18-52$ & $31-62$ & \\
\hline \multicolumn{4}{|c|}{ 3. Berat badan (kg) } \\
\hline $\mathrm{X}(\mathrm{SB})$ & $59(7,8)$ & $62,4(5,9)$ & $t=0,99$ \\
\hline Rentang & $47-70$ & $55-75$ & $p=0,336$ \\
\hline \multicolumn{4}{|c|}{ 4. Tinggi badan $(\mathrm{Cm})$} \\
\hline$X(S B)$ & $156,8(7,1)$ & $159,2(8,1)$ & $t=0,67$ \\
\hline Rentang & $145-167$ & $150-170$ & $p=0,514$ \\
\hline \multicolumn{4}{|l|}{ 5. BMI } \\
\hline $\mathrm{X}(\mathrm{SB})$ & $24,0(3,0)$ & $24,6(2,1)$ & $t=0,50$ \\
\hline Rentang & $21,2-30,6$ & $21,7-27,3$ & $p=0,625$ \\
\hline
\end{tabular}

$p_{\mathrm{EF}} \quad=$ nilai $\mathrm{p}$ berdasarkan uji eksak Fisher

$\mathrm{t} \quad=$ uji $\mathrm{T}$

$\mathrm{Z}_{\mathrm{M}-\mathrm{W}}=$ uji Mann - Whitney 
Pengaruh Asam Traneksamat terhadap Pendarahan Perioperatif

Perbandingan hasil pengukuran berbagai variabel dapat dilihat pada Tabel 2. Lama operasi rata-rata lebih rendah pada kelompok perlakuan $(216,7 \pm 49,2$ menit $)$ dibandingkan dengan kelompok kontrol ( $253 \pm 58,1$ menit), tetapi perbedaan ini tidak bermakna $(p=0,201)$.

Tabel 2. Perbandingan berbagai variabel yang diukur pada kelompok perlakuan dan kontrol

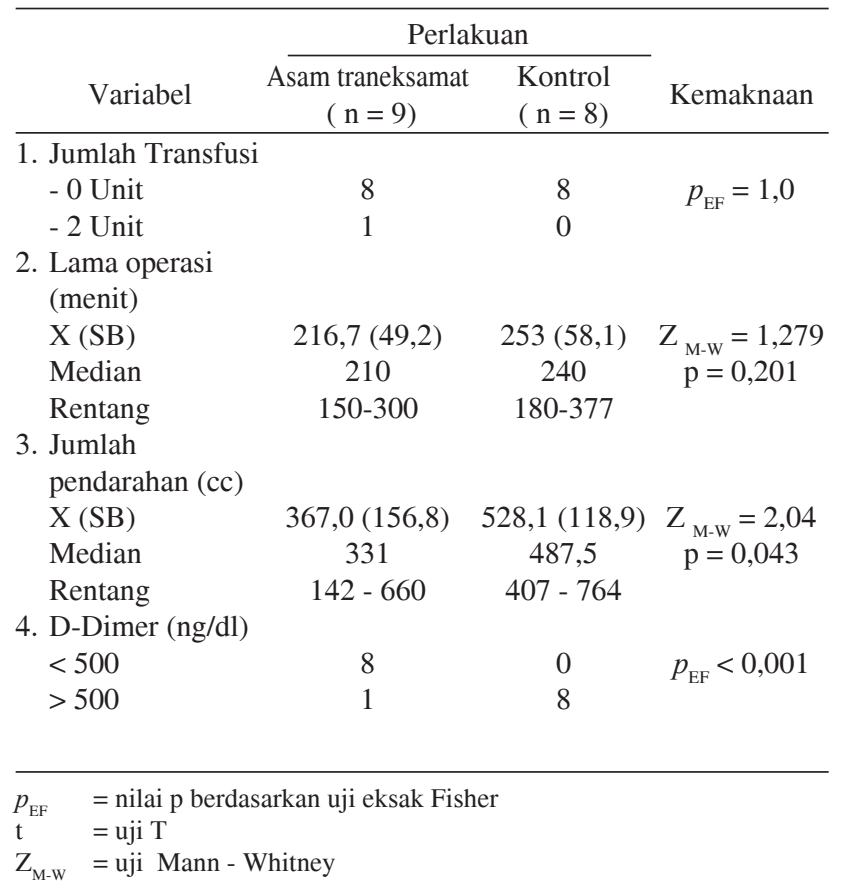

Jumlah pendarahan rata-rata pada kelompok perlakuan adalah $367,0+156,8 \mathrm{cc}$ dengan median $331 \mathrm{cc}$ dan rentang $142-660$ cc. Jumlah pendarahan ini secara bermakna lebih sedikit dibandingkan dengan kelompok kontrol $\left(\mathrm{Z}_{\mathrm{M}-\mathrm{W}}=2,04\right.$; $p=0,043)$. Jumlah pendarahan rata-rata pada kelompok kontrol adalah 528,1 + 118,9 cc dengan median 487,5 cc, dan rentang $407-764$ cc.

Hanya satu penderita yang mendapat transfusi darah pascaoperasi sebanyak 2 unit. Pemberian transfusi tersebut dilakukan setelah pengambilan darah untuk pemeriksaan DDimer. Penderita ini memiliki kadar hemoglobin praoperasi 9,8 g/dl dan hematokrit $30 \%$, dengan estimasi pendarahan perioperatif $331 \mathrm{cc}$, kadar hemoglobin pascaoperasi turun menjadi 8,5 g/dl dan hematokrit 25\%. Dokter yang merawat memberikan transfusi sebanyak 2 unit dengan kadar hemoglobin pascatransfusi 10,3 g/dl dan hematokrit $32 \%$. Pemberian transfusi pada penderita ini lebih disebabkan oleh keadaan praoperasi.

Distribusi volume tumor pada kedua kelompok tidak berbeda secara bermakna $(p=0,194)$, demikian juga persen volume tumor yang terangkat pada kedua kelompok $(p=0,405)$ (Tabel 3.) Penilaian terhadap korelasi antara jumlah pendarahan dengan lama operasi dan persen volume tumor yang terangkat pada kedua kelompok dapat dilihat pada Tabel 4.

Tabel 3. Perbandingan rata-rata volume tumor antara kelompok perlakuan dan kontrol

\begin{tabular}{lccc}
\hline & \multicolumn{2}{c}{ Perlakuan } & \\
\cline { 2 - 3 } \multicolumn{1}{c}{ Karakteristik } & $\begin{array}{c}\text { Asam traneksamat } \\
(\mathrm{n}=9)\end{array}$ & $\begin{array}{c}\text { Kontrol } \\
(\mathrm{n}=8)\end{array}$ & Kemaknaan \\
\hline 1. Volume tumor & $30,9(11,8)$ & $33,3(5,8)$ & $\mathrm{ZM}-\mathrm{W}=1,30$ \\
X (SB) & 27,4 & 30,7 & $\mathrm{p}=0,194$ \\
Median & $19,5-57,6$ & $28,7-41,86$ & \\
Rentang & & & \\
2. Volume & & & \\
terangkat (\%) & $77,2(17,2)$ & $74,3(12,7)$ & $\mathrm{ZM}-\mathrm{W}=0,832$ \\
X (SB) & 80 & 80 & $\mathrm{p}=0,405$ \\
Median & $40-95$ & $50-90$ & \\
Rentang & & &
\end{tabular}

$\mathrm{Z}_{\mathrm{M}-\mathrm{W}}=$ uji Mann - Whitney

Tabel 4. Korelasi antara jumlah pendarahan dengan lama operasi dan persen volume tumor yang terangkat pada kelompok perlakuan dan kontrol

\begin{tabular}{|c|c|c|c|c|}
\hline & Perla & kuan & & \\
\hline $\begin{array}{c}\text { Hasil } \\
\text { Pemeriksaan }\end{array}$ & $\begin{array}{c}\text { Asam } \\
\text { Traneksamat } \\
(n=9)\end{array}$ & $\begin{array}{l}\text { Kontrol } \\
(\mathrm{n}=8)\end{array}$ & $\mathrm{t}$ & Nilai $\mathrm{p}$ \\
\hline 1. $\mathrm{Hb}(\mathrm{g} / \mathrm{dl})$ & & & & \\
\hline Praop & $\left.12,62(1,66)^{*}\right)$ & $13,45(1,66)$ & 1,03 & 0,320 \\
\hline Pascaop & $11,82(1,84)$ & $11,98(1,80)$ & 0,17 & 0,866 \\
\hline $\mathrm{t}_{\text {paired }}$ & 5,82 & 7,78 & & \\
\hline Nilai p & $<0,001$ & $<0,001$ & & \\
\hline$\%$ penurunan & $6,6(3,85)$ & $11,13(4,24)$ & 2,31 & 0,035 \\
\hline 2. Ht (\%) & & & & \\
\hline Praop & $38,56(3,79)$ & $41,12(3,76)$ & 1,37 & 0,192 \\
\hline Pascaop & $35,78(5,07)$ & $35,5(4,47)$ & 0,12 & 0,907 \\
\hline $\mathrm{t}_{\text {paired }}$ & 3,85 & 7,03 & & \\
\hline Nilai p & 0,005 & 0,001 & & \\
\hline$\%$ penurunan & $7,47(6,06)$ & $13,79(5,47)$ & 2,25 & 0,040 \\
\hline $\begin{array}{l}\text { 3. Trombosit } \\
\text { (ribu / mm3) }\end{array}$ & & & & \\
\hline Praop & $258(75,6)$ & $285,9(25,2)$ & 0,99 & 0,337 \\
\hline Pascaop & $206,8(83,1)$ & $183,2(42,8)$ & 0,72 & 0,483 \\
\hline $\mathrm{t}_{\text {paired }}$ & $\begin{array}{c}2,36 \\
0,046\end{array}$ & $\begin{array}{c}5,62 \\
<0,001\end{array}$ & & \\
\hline $\begin{array}{l}\text { Nilai } \mathrm{p} \\
\% \text { penurunan }\end{array}$ & $\begin{array}{c}0,046 \\
19,2(24,4)\end{array}$ & $\begin{array}{c}<0,001 \\
35,3(17,3)\end{array}$ & 1,56 & 0,140 \\
\hline$*$ & ai rata-rata dan & impangan baku & & \\
\hline $\mathrm{t}=\mathrm{u}$ & & & & \\
\hline$\%$ penurunan $=($ & op- pascaop) & eop x $100 \%$. & & \\
\hline
\end{tabular}


Korelasi antara jumlah pendarahan dengan lama operasi, bermakna pada kelompok perlakuan $(p=0,037)$ sedangkan pada kelompok kontrol tidak bermakna $(p=0,363)$. Korelasi antara jumlah pendarahan dan lama operasi pada kelompok perlakukan dapat dilihat pada grafik sactterplot Gambar 1. dengan persamaan regresi linier. Korelasi antara jumlah pendarahan dengan persen volume tumor yang terangkat pada kedua kelompok tidak bermakna $(p>0,05)$.

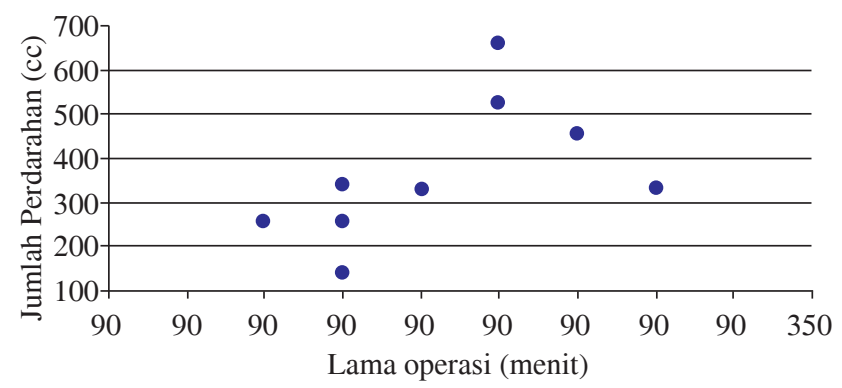

Gambar 1. Grafik scatterplot korelasi antara jumlah pendarahan dan lama operasi pada kelompok perlakuan, mengikuti persamaan regresi linier $\mathrm{P}=0,454+(1,692 \mathrm{x}$ lama operasi $)$

Gambaran patologi anatomi dalam penelitian ini dikelompokkan atas high grade glioma (HGG) dan low grade glioma (LGG). Pengelompokan ini didasarkan pada sistem Kernohan. ${ }^{7}$ Distribusi gambaran patologi anatomi pada kelompok perlakuan dan kontrol tidak berbeda secara bermakna $\left(p_{\mathrm{EF}}=0,131\right)$.

\section{Pengaruh Asam Traneksamat terhadap Kadar Hemoglobin,} Hematokrit, dan Trombosit

Perbandingan rata-rata penurunan kadar hemoglobin, hematokrit, dan trombosit pra dan pascaoperasi dari kelompok perlakuan dan kontrol dapat dilihat pada Tabel 5. Distribusi kadar hemoglobin, hematokrit, dan trombosit pra dan pascaoperasi pada kedua kelompok tidak berbeda secara bermakna $(p>0,05)$. Perbedaan ditemukan pada persen penurunan kadar hemoglobin dan hematokrit antara kelompok perlakuan dengan kontrol. Penurunan kadar hemoglobin antara pra dan pascaoperasi berbeda secara sangat bermakna baik pada kelompok perlakuan maupun kontrol $(p<0,001)$. Persen penurunan kadar hemoglobin pada kelompok perlakuan adalah $6,6 \pm 3,85 \%$, sedangkan pada kelompok kontrol 11,13 $\pm 4,24$ $\%$. Persen penurunan pada kedua kelompok ini berbeda secara bermakna $(p=0,035)$. Demikian juga dengan hematokrit, penurunan hematokrit antara pra dan pascaoperasi berbeda sangat bermakna baik pada kelompok perlakuan maupun kontrol $(p<0,005)$.

\section{DISKUSI}

Hasil penelitian ini juga menunjukkan kecenderungan glioma pada laki-laki (64,7\%). Hasil ini konsisten dengan data dari Central Brain Tumor Registry of the United States tahun
1997, kecenderungan glioma pada laki-laki mencapai 59\%. ${ }^{6}$

Distribusi jenis tumor tidak berbeda secara bermakna pada kelompok perlakuan dan kontrol, semua lokasi tumor yang terletak supratentorial menyebabkan teknik operasi dan tingkat kesulitan tidak terlalu berbeda pada masing-masing kelompok. Lokasi dan jenis tumor sangat memengaruhi lamanya operasi, dengan demikian secara tidak langsung akan memengaruhi jumlah perdarahan. ${ }^{1}$ Jumlah pendarahan pada pembedahan glioma sangat dipengaruhi oleh rembesan pendarahan yang terjadi (oozing) karena pembuluh darah yang memberikan kontribusi terhadap tumor umumnya berukuran kecil dan banyak. Berbeda dengan operasi meningioma yang memiliki pembuluh darah utama yang memberikan kontribusi terhadap tumor dan ukuran pembuluh darah ini relatif besar. Jumlah pendarahan pada operasi meningioma sangat dipengaruhi oleh pembuluh darah utama tersebut. Setelah pembuluh darah utama yang memberikan kontribusi terhadap meningioma berhasil dibunuh, maka rembesan pendarahan akan sangat berkurang. Pada penelitian ini, secara umum dapat dikatakan bahwa operasi glioma tidak membutuhkan transfusi darah, sehingga pengaruh pemberian asam traneksamat untuk mengurangi kebutuhan transfusi darah tidak dapat dinilai dalam penelitian ini $\left(p_{\mathrm{EF}}=1,0\right)$.

Selama operasi glioma berlangsung, akan terus diikuti oleh rembesan pendarahan karena banyaknya pembuluh darah kecil yang memberikan kontribusi terhadap tumor. Hasil penelitian ini menunjukkan bahwa pemberian asam traneksamat dosis tunggal praoperasi $20 \mathrm{mg} / \mathrm{kgBB}$ dapat mengurangi jumlah pendarahan $(p<0,05)$. Hemostasis pada pembuluh darah kecil sangat dipengaruhi oleh keseimbangan kaskade koagulasi dan fungsi fibrinolisis, sedangkan pada pembuluh darah besar dan sedang lebih banyak dipengaruhi oleh tindakan selama operasi seperti kauterisasi dengan bipoler, penempatan hemoclip, dan lain-lain. Hasil ini konsisten dengan pengaruh asam traneksamat untuk menurunkan aktifitas fibrinolisis yang dibuktikan dengan kadar D-Dimer yang lebih rendah pada kelompok perlakuan. Perbedaan kadar D-Dimer pada kedua kelompok tersebut sangat bermakna $\left(p_{\mathrm{EF}}<0,001\right)$. Hanya satu penderita pada kelompok perlakuan yang menunjukkan kadar D-Dimer $>500 \mathrm{ng} / \mathrm{dl}$, dengan estimasi jumlah pendarahan 660 cc. Kadar D-Dimer pada penderita ini diperkirakan berhubungan dengan gambaran patologi anatomi berupa glioblastoma multiforme.

Pendarahan intratumoral kadang-kadang menyertai glioblastoma multiforme. Banyak penelitian yang membuktikan bahwa aktifitas tissue plasminogen aktivator (t-PA) berhubungan dengan agresifitas tumor, luasnya infiltrasi tumor ke jaringan otak sekitarnya dan kejadian pendarahan intratumoral. ${ }^{8}$ Kadar t-PA yang tinggi tentunya akan berhubungan dengan aktifitas fibrinolisis yang tinggi sehingga jumlah produk degradasi fibrin juga meningkat yang terukur sebagai peningkatan kadar D-Dimer. 
Hemostasis yang normal membutuhkan tiga elemen dasar 1) jumlah trombosit yang adekuat dan berfungsi dengan baik, 2) tersedianya faktor pembekuan yang cukup, dan 3) pengendalian mekanisme antikoagulan alamiah pada daerah pendarahan atau sering disebut sebagai fungsi fibrinolisis. ${ }^{1}$ Waktu pendarahan mulai memanjang jika jumlah trombosit turun dibawah $100000 / \mu 1 .{ }^{9}$ Semua penderita dalam penelitian memiliki jumlah trombosit pra dan pascaoperasi diatas 100 000/ $\mu$ l dan profil koagulasi pra dan pascaoperasi dalam batas normal.

Kadar trombosit pada kelompok perlakuan menurun secara bermakna pada pengukuran pascaoperasi dibandingkan dengan praoperasi $(p=0,046)$, dengan persen penurunan 19,2 $\pm 4,4 \%$. Kelompok kontrol memperlihatkan penurunan jumlah trombosit yang sangat bermakna $(p<0,001)$ dengan persen penurunan $35,3 \pm 17,3 \%$. Walaupun persen penurunan ini diantara kedua kelompok ini tidak berbeda secara bermakna ( $p=0,140)$, tetapi penurunan jumlah trombosit jelas lebih banyak pada kelompok kontrol. Penurunan jumlah trombosit yang sangat bermakna pada kelompok kontrol menunjukkan bahwa beban aktivitas koagulasi pada kelompok kontrol lebih berat dibandingkan dengan kelompok perlakuan. Hal ini dapat dijelaskan dengan memahami prinsip dasar bahwa pada proses hemostasis yang normal dibutuhkan keseimbangan yang baik antara fungsi koagulasi dan fungsi fibrinolisis. Jika fungsi koagulasi lebih dominan dibandingkan dengan fungsi fibrinolisis, maka penderita cenderung mengalami trombosis. Sedangkan jika sebaliknya, maka penderita akan cenderung mengalami perdarahan.

Keseimbangan antara fungsi koagulasi dan fungsi fibrinolisis ini dapat diartikan secara sederhana sebagai keseimbangan antara fungsi pembentukan bekuan darah dan fungsi penguraian atau degradasi bekuan darah. Kedua fungsi tersebut tergantung pada beberapa rangkaian reaksi awal dan dapat dipengaruhi oleh berbagai hal. Oleh sebab itu, gangguan keseimbangan kedua fungsi ini dapat diintervensi pada kedua sisi. Penderita glioma yang sedang mendapat deksametason akan mengalami gangguan pada fungsi koagulasi, disamping itu terjadi peningkatan aktifitas fibrinolisis selama operasi. ${ }^{2}$ Fungsi koagulasi yang terganggu ditambah dengan aktifitas fibrinolisis yang meningkat akan menyebabkan rembesan pendarahan yang sulit berhenti. Sebagai akibatnya, fungsi koagulasi akan terbebani dengan peningkatan konsumsi faktor pembekuan dan trombosit. Beban tersebut dapat dikurangi dengan menurunkan aktifitas fibrinolisis selama operasi dengan pemberian asam traneksamat praoperasi dosis tunggal. Asam traneksamat dalam hal ini berperan menghambat konversi plasminogen menjadi plasmin dan pada konsentrasi yang relatif lebih tinggi dapat menghambat aktivitas plasmin. Korelasi antara jumlah pendarahan dan lama operasi pada kelompok perlakukan yang terlihat pada grafik sactterplot (Gambar 1.) dengan persamaan regresi linier, gambaran ini menunjukkan hubungan antara pengaruh asam traneksamat yang semakin menurun dengan masa operasi yang semakin lama. Perbedaan regresi linier ini tidak ditemukan pada kelompok kontrol. Hasil ini memperkuat pendapat bahwa asam traneksamat praoperasi dosis tunggal memang mempengaruhi keseimbangan antara kaskade koagulasi dan fungsi fibrinolisis. Asam traneksamat dalam hal ini menghambat fungsi fibrinolisis sehingga kaskade koagulasi bekerja lebih optimal.

Penggunaan antifibrinolitik yang lama dan berulang-ulang dapat merugikan bagi susunan saraf. Percobaan pada mencit menunjukkan bahwa adanya fibrin dalam matrik ekstraselluler dapat memperlambat regenerasi saraf. ${ }^{10,11}$ Oleh sebab itu, adanya tissue plasminogen aktivator (tPA) merupakan suatu mekanisme protektif terhadap cedera saraf. Sebagai implikasinya bahwa penggunaan antifibrinolitik pada cedera jaringan saraf dapat menghambat regenerasi saraf. Penggunaan antifibrinolitik untuk mengurangi pendarahan intraoperatif dan pascaoperasi jangan diberikan terlalu lama karena penggunaan yang lama dan berulang dapat menghambat regenerasi saraf, menyebabkan deep vein thrombosis pada tungkai, emboli paru, dan lain-lain.12 Sebaiknya penggunaan antifibrinolitik hanya diberikan pada saat operasi atau berupa dosis profilaksis, jika diperlukan dapat dipertahankan selama 24 jam setelah operasi. Dalam penelitian ini tidak ditemukan efek samping pemberian asam traneksamat praoperasi.

\section{SIMPULAN}

Pemberian asam traneksamat praoperasi mengurangi jumlah pendarahan perioperatif pada penderita tumor otak yang sedang mendapat pengobatan deksamethason. Pengaruh asam traneksamat semakin menurun jika operasi semakin lama.

\section{DAFTAR PUSTAKA}

1. Palmer JD, Francis JL, Pickard JD, Iannotti F. The efficacy and safety of aprotinin for hemostasis during intracranial surgery. J Neurosurg. 2003; 98: 1208-16.

2. Badie B, Schartner JM, Paul J, Bartley BA, Vorpahl J, Preston K. Dexamethason - induced abolition of the inflammatory response in experimental glioma model: a flow cytometry study. J Neurosurg. 2000; 93: 634-9.

3. Ulfarsson E, Lindquist C, Roberts M, Rahn T, Lindquist M, Thoren $\mathrm{M}$, et al. Gamma knife radiosurgery for craniopharyngiomas : long-term results in the first Swedish patients. J Neurosurg. 2002; 97(Suppl 5): 613-22.

4. Steward DJ. Assessment of blood loss. In : Steward DJ, editor. Manual of pediatric anesthesia. 3rd ed. New York : Churchill Livingstone; 1990. p. 67-71

5. Stevens RD, Van Gessel E, Flory N, Fournier R, Gamulin Z. Lumbar plexus block reduces pain and blood loss associated with total hip arthroplasty. Anesthesiology. 2000; 93(1): 115-21.

6. Wrensch MR, Minn Y, Bondy ML. Epidemiology. In : Bernstein M, Berger MS, editors. Neuro-oncology the essentials. New York: Thieme; 2000. p. 2-17.

7. Greenberg MS, editor. Handbook of neurosurgery. 5th ed. New 
York: Thieme; 2001.

8. Sawaya R, Highsmith R. Plasminogen activator activity and molecular weight patterns in human brain tumors. J Neurosurg. 1988; 68: 73-9.

9. Wachfogel YT, Musial J, Jenkin B. Loss of platelet È2-adrenergic receptors during stimulated extracorporeal circulation: prevention with prostaglandin E1. J Lab Clin Med. 1985; 105: 601-7.

10. Akassoglou K, Kombrinck KW, Degen JL, Strickland S. Tissue plasminogen activator-mediated fibrinolysis protects against axonal degeneration and demyelination after sciatic nerve injury. J Cell Biol. 2000; 149: 1157-66.

11. Akassoglou K, Yu WM, Akpinar P, Strickland S. Fibrin inhibits peripheral nerve regeneration by arresting Schwann cell differentiation. Neuron. 2002; 33: 861-75.

12. Erstad BL. Systemic hemostatic medications for reducing surgical blood loss. Ann Pharmacother.2001; 35: 925-34. 